\footnotetext{
Keywords:

Brazilian pine

Clonal forestry

Grafting

Growing habits
}

Historic:

Received 06/10/2017

Accepted 19/12/2017

Palavras chave:

Pinheiro brasileiro

Silvicultura clonal

Enxertia

Hábitos de crescimento

${ }^{+}$Correspondence: gasparufpr@gmail.com
Rozimeiry Gomes Bezerra Gaspar ${ }^{1+}$, Ivar Wendling², Carlos Andre Stuepp ${ }^{3}$, Alessandro Camargo Angelo'

\section{ROOTSTOCK AGE AND GROWTH HABIT INFLUENCE TOP GRAFTING IN Araucaria angustifolia}

ABSTRACT: The objective of this study was to evaluate the technical viability and influence of the rootstock age and grafts growth habit on Araucaria angustifolia top grafting. Two rootstocks ( 8 and 35 -year-old) were grafted with grafts originating from two growth habits (orthotropic and plagiotropic). We used the patch grafting technique in the middle and upper third of the crown of 8-year-old trees, and in the middle and lower third of 35-year-old trees, always near the apex in primary branches. The experiments were performed during the fall and spring/20I5. The treatments consisted of: 8-year-old rootstocks and orthotropic grafts; 8-year-old rootstocks and plagiotropic grafts; 35-yearold rootstocks and plagiotropic grafts; 35-year-old rootstocks and orthotropic grafts. We evaluated graft survival throughout the experiment and at 16 months, we evaluated their survival, emission, and number and average length of sprouts. Top grafting is technically feasible for araucaria, with better results using younger rootstocks (8-year-old), especially with plagiotropic propagules and grafting in fall/2015 (71.9\%). Growth habits of the grafts are maintained identically as original, independently of rootstock growth habit.

\section{IDADE DO PORTA-ENXERTO E HÁBITO DE CRESCIMENTO INFLUENCIAM NA ENXERTIA DE COPA EM Araucaria angustifolia}

RESUMO: O presente trabalho objetivou avaliar a viabilidade técnica e a influência da idade do porta-enxerto e do hábito de crescimento na enxertia de copa em Araucaria angustifolia. Foram utilizados porta-enxertos de duas idades (8 e 35 anos), com enxertos originários de dois hábitos de crescimento (ortotrópicos e plagiotrópicos). A enxertia foi realizada por borbulhia de placa, no terço médio e superior da copa das árvores de 8 anos e no terço médio e inferior das árvores de 35 anos, sempre próximo ao ápice em ramos primários. Os experimentos foram instalados em duas épocas, no outono e na primavera de 2015. Os tratamentos consistiram de: Porta enxertos com 8 anos de idade e enxertos ortotrópicos; Porta enxertos com 8 anos de idade e enxertos plagiotrópicos; Porta enxertos com 35 anos de idade e enxertos plagiotrópicos; Porta enxertos com 35 anos de idade e enxertos ortotrópicos. Foram avaliadas a sobrevivência dos enxertos ao longo do experimento e aos 16 meses, sua sobrevivência, a emissão, número e comprimento médio de brotações. A enxertia de copa é viável tecnicamente para araucária. $\mathrm{O}$ uso de porta-enxertos mais jovens (8 anos) é favorável a sobrevivência dos enxertos, especialmente quando da utilização de propágulos plagiotrópicos e enxertia realizada no outono $(71,9 \%)$. O habito de crescimento dos enxertos se manteve idêntico ao original,

Federal University of Paraná - Curitiba, Paraná, Brazil

2 Embrapa Florestas, Colombo, Paraná, Brazil

${ }^{3}$ State University of Ponta Grossa, Ponta Grossa, Paraná, Brazil 
independentemente do habito de crescimento dos porta-enxertos.

\section{INTRODUCTION}

Over the years, the Brazilian forestry sector has focused on the improvement of Eucalyptus and Pinus species, which represent $72.1 \%$ and $20.2 \%$ of the total forest plantation area in Brazil, respectively. Other species represent $7.6 \%$ of the total forest plantation, with araucaria making up $0.5 \%$ of this area (IBÁ, 20I7).

Araucaria angustifolia (Bertol.) Kuntze, commonly known as araucaria, Brazilian pine, or Paraná pine, is the only species of the genus that naturally occurs in Brazil, predominantly in the Southern region, as well as in Argentina and Paraguay (GONÇALVES et al., 20/4). This species provides excellent quality wood for several purposes (ZANETTE et al., 2017), which is one of the reasons why it was so intensely exploited at the end of the 19th century (DANNER et al., 2012; NAZARENO; REIS, 2014). Additionally, their seeds are highly prized for human and animal consumption, as they are rich in starch, low in calories, a source of magnesium, and have a low glycemic index (CORDENUNSI et al., 2004).

Like most conifers, araucaria propagation is made by seeds (KUHN; MARIATH, 20I4). Due to low longevity of the seeds, high genetic variability, and undefined sex until reproductive maturity, some studies have aimed to develop vegetative propagation techniques (DIAS et al., 20I2). Among such techniques, grafting became potential for plant production, as it allows the control of characteristics, such as sex and genetic qualities of parent trees, and has been improved over the years for araucaria (GURGEL; GURGEL-FILHO, 1967; KAGEYAMA; FERREIRA, 1975; WENDLING, 20I I; ZANETTE et al., 20II; 20I7; WENDLING et al., 20I6).

Grafting using patch graft technique is considered viable to form orchards for early araucaria nuts production, with more than $80 \%$ survival rate with orthotropic shoots from the crown of adult plants (WENDLING, 2015). Top grafting on adult rootstocks was effective in reducing the cycle for Pinus breeding programs, with precocious formation of strobili and seeds and reduced intervals between generations (ALMQVIST, 20 I 3a; 20 I 3b, PEREZ et al., 2007). However, there is no literature for its application in araucaria, which could provide new perspectives for the species breeding programs.

Therefore, this study aimed to evaluate the technical viability, and the influence of rootstocks age and growth habit of grafts on araucaria top grafting during fall and spring.

\section{MATERIAL AND METHODS}

The experiments were conducted from April/2015 to June/2017, on trees established at Embrapa

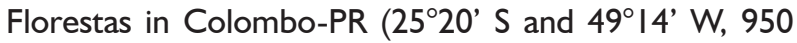
$\mathrm{m})$. According to the Köppen classification, the climate of the region is type $\mathrm{Cfb}$ and is temperate, with the coldest month between $-3^{\circ} \mathrm{C}$ and $18{ }^{\circ} \mathrm{C}$, always humid, with rains well distributed throughout the year, and the average temperature of hottest month is below $22^{\circ} \mathrm{C}$.
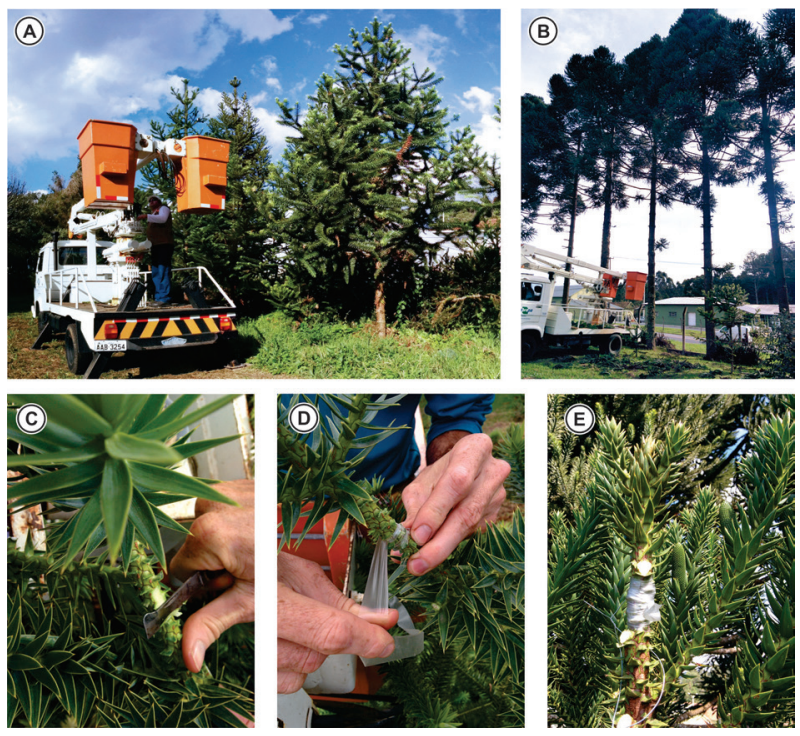

FIGURE I General characterization of the experiments: (A) 8-year-old parent trees; (B) 35-year-old parent trees; $(C)$ preparation of the rootstock to receive the graft; (D) patch placement with grafting tape and $(E)$ finished graft.

For grafting experiments, we used pruning shears to remove the needles in the grafted area, a pocketknife to make the incision in the graft and rootstock, and plastic film to fix the graft until joined. Eight and 35-year-old adult araucaria plants were used as rootstocks (Figure $I A$ and $B)$.

We used two types of propagules, orthotropic and plagiotropic, according to their original growth orientation, which both came from a 2-year-old clonal orchard formed from pruning shoots of 33-year-old trees (WENDLING et al., 2009). More recently, Zanette et al. (2017) referred to the orthotropic parts of araucaria as trunk and plagiotropic as primary branches (those used in the present study) and secondary branches. At grafting time, the grafts were collected from the clonal garden, packed in water, and kept in the shade. We used the patch grafting technique, which was performed on the middle and upper third of the crown for the 8-year-old 
trees and in the middle and lower third for the 35-yearold trees, always near the apex of the primary branches.

To facilitate the work and improve the quality of the technique application, we removed about $10 \mathrm{~cm}$ of the needles along the trunk of the rootstocks prior to grafting. A shield $(4 \mathrm{~cm} \times 1.3 \mathrm{~cm})$ was then removed, and the graft (path) was conditioned, ending with a plastic wrap (grafting tape) covering the graft (Figure IC, D, and E). The plastic tape was removed from the grafts after 45 days, and after 90 days, the sprouts of the rootstocks above de grafts were pruned. Subsequently, all the new sprouts that emerged from rootstocks were pruned, in order to avoid competition with live grafts.

We used four treatments, corresponding to the age of the rootstocks and growth orientation of the propagules used for grafting (grafts), with: (TI) 8-yearold rootstocks and orthotropic grafts; (T2) 8-year-old rootstocks and plagiotropic grafts; (T3) 35-year-old rootstocks and plagiotropic grafts; (T4) 35-year-old rootstocks with orthotropic grafts. The experiments were installed during two distinct seasons, the first in fall/20I5 and the second in spring/20I5.

We evaluated the survival at $3,8,9,11,12$, and 16 months for grafts made in fall/20I5 and, at 3, 4, 8, and 16 months for grafts from spring/2015. For both seasons, we evaluated shoot sprouting percentage, mean number of sprouts/grafts, and average length of sprouts 16 months after grafting.

To evaluate graft survival, we applied a completely randomized design with a $2 \times 2$ factorial arrangement, composed of two rootstocks ages (eight and 35-yearold) and two grafts growth habits (orthotropic and plagiotropic), with four replications of eight grafts per experimental unit, installed in the fall and spring/2015. Due to the high mortality rate observed in some treatments, a completely randomized design with different numbers of replicates was adopted for the variables percentage of emission, and number and average length of sprouts in the two seasons. Homogeneity of the treatment variances were evaluated using the Bartlett test and the variables with significant differences using the $F$ test had their means compared by the Tukey test at the $5 \%$ probability level.

\section{RESULTS AND DISCUSSION}

The graft survival results showed a significant interaction $(P<0.05)$ between growth habit (orthotropic and plagiotropic) and the age of rootstocks (eight and 35 -year-old) only at 16 months after grafting, for both seasons (fall and spring/20I5).

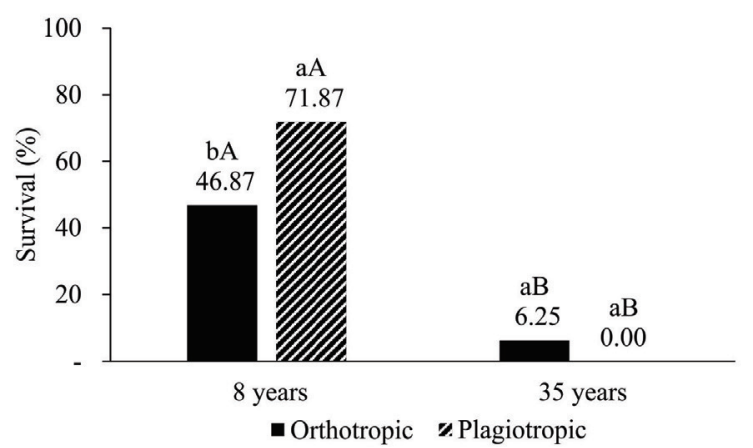

FIGURE 2 Position tree planting in the Cartesian plane trees in 1875 (Left,) and position of the sample with 200 trees (Right).

We recorded the highest percentages of graft survival in fall/2015 for plagiotropic sprouts on young rootstocks (8-year-old). However, the use of adult rootstocks (35-year-old) did not show the effect of the propagules origin, with a low percentage of survival after 16 months (Figure 2).

The reduced survival rates of both plagiotropic and orthotropic grafts for adult rootstocks may be related to the lower metabolism of the branches located in the middle and lower third of the crown, along with the higher physiological maturity of the branches of the adult rootstocks (35-year-old). One of the determining factors when choosing rootstocks for forest species is the growth similarity and age between graft and rootstock (JAYAWICKRAMA et al., 199I). Similarly, vigor and stage of development have been determinant factors in grafting success, and favor young araucaria branches compared to those closer to senescence (WENDLING et al., 2017). The effect of branch senescence on the survival of top grafts was described for Pinus elliottii var. elliottii, with highest survival rates for grafts in the middle portion of the crown, followed by the apex, and lower percentages for basal survival (PEREZ et al., 2007).

The loss of the physiological vigor is a result of plant maturation, which causes reduced growth rates and increased senescence (MENCUCCINI et al., 2007; HARTMANN et al., 20Il; WENDLING et al., 2014), factors defined as preponderant in the process of araucaria graft survival (WENDLING et al., 2016). The effects generated by using rootstocks with different ages have been reported for Picea rubens and Pseudotsuga menziesii, which showed inhibited growth when using adult rootstocks and increased vigor with the use of young ones (BOND et al., 2007; GREENWOOD et al., $2010)$, thus demonstrating the importance of rootstock's ontogenetic age for the survival and vigor of grafts. 
The affinity between the graft and rootstock is a key factor in the grafting process and encompasses morphological, anatomical, physiological, and biochemical aspects of a plant (YIN et al., 20I2). Physiological affinity refers to a plant's capacity to transport nutrients and organic compounds from the root to the crown and vice versa, whereas the anatomical affinity is related to the intimate association of the exchangeable tissues which form a continuous connection that can be compromised when the crown and the rootstock present differences in cell size, shape, and consistency (SIMON, 197I).

For araucaria, the morpho-anatomical affinity has been described as one of the preponderant factors for success in vascular connections, and the similarity between propagules in respect to physiology, anatomy, tissue consistency, size, and vigor between graft and rootstock should be respected (WENDLING et al., 2017).

The morphological and anatomical affinity between graft and rootstock may also explain the greater survival of grafts from plagiotropic branches, especially in fall, when survival rates were higher (reaching $71.9 \%$ ) after 16 months (Figure 3). In general, the greater the affinity between graft and rootstock, the higher the chances of grafting success, therefore, the more mature and complex the organs or tissues, the more difficult grafting success becomes (ZUNTI, I972; RONCATTO et al., 20I I).

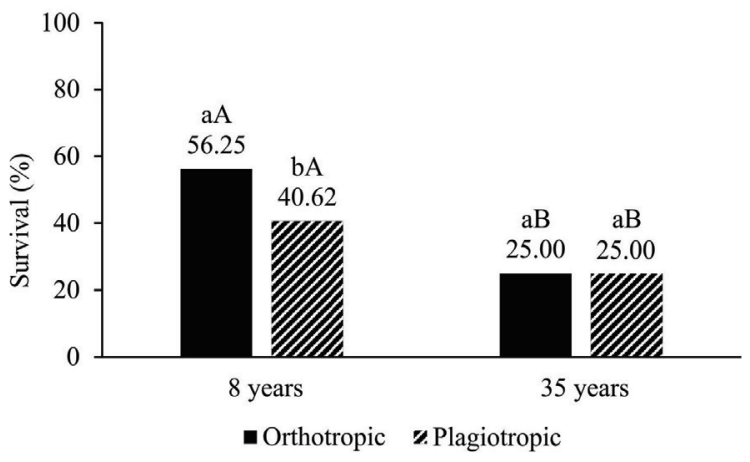

FIGURE 3 Survival of $A$. angustifolia grafts as a function of growth habit and age of rootstock at 16 months after grafting performed in spring/20I5. Means with the same lowercase letter within the age group or same upper case letter between ages do not differ according to the Tukey test $(\mathrm{P}<0.05)$.

We found higher percentages of graft survival in the spring/2015 using propagules from orthotropic shoots when compared to those of plagiotropic origin applied to young rootstocks (8-years-old). For 35-yearold rootstocks, we did not observe an effect of the origin of the propagules (Figure 3).
We observed the highest percentages of graft survival after 16 months in 8-year-old rootstocks, regardless of grafting time and growth habit. When comparing the two grafting periods, we observed a higher percentage of graft survival in the spring, when applied to 35 -year-old rootstocks, which can be considered a good indicator for future research.

Throughout the 16 months, we observed a tendency for decreased graft survival for both grafting times (Figure 4). Previous studies evaluating the grafting techniques for young araucaria plants (up to three years), usually evaluated graft survival until a period of up to 6 months (OLIVEIRA, 20I0; ZANETTE et al., 20ll; CONSTANTINO; ZANETTE, 2015; WENDILING, 20II; 2015; WENDILING et al., 2016). Herein, we observed a reduction in survival percentages, which
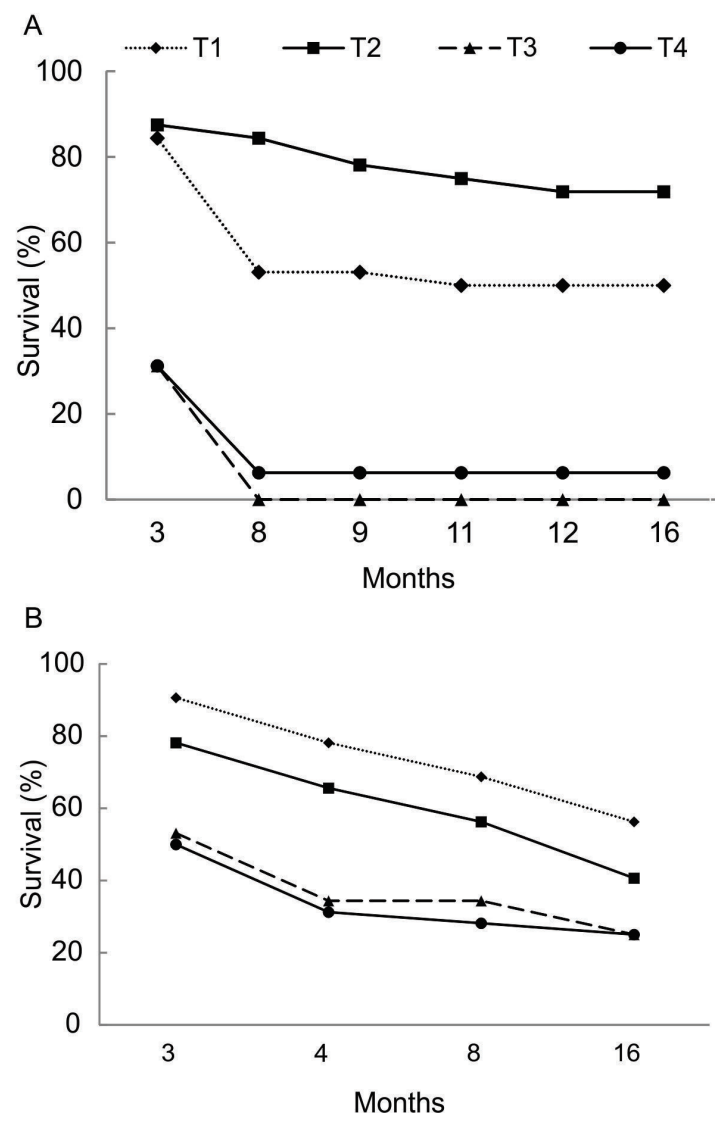

FIGURE 4 Survival of A. angustifolia grafts as a function of growth habit and age of rootstocks at 16 months after grafting in autumn/2015 (A) and spring/20I5 (B). Where: TI: 8-year-old rootstocks and orthotropic grafts; T2: 8-year-old rootstocks and plagiotropic grafts; T3: 35-year-old rootstocks and plagiotropic grafts; T4: 35-year-old rootstocks and orthotropic grafts. 
stabilized at 16 months after grafting. However, the faster the union (welding) of the graft and rootstock tissues, the greater the operation success, considering that this efficiency decreases the time that the graft is at risk of dehydration (HARTMANN et al., 20l I).

During the unification process, it is common calluses formation on both the scion and rootstock, which causes differentiation between the two and culminates in the recomposition of the plant's vascular system (MARTÍNEZBALLESTA et al., 20I0; HARTMANN et al., 20I I). The poor quality of this union is often related to a low callus formation, caused by poor contact between the scion and rootstock at the time of grafting, resulting in reduced growth rates and graft mortality (JOHKAN et al., 2009; MARTÍNEZ-BALLESTA et al., 20I0; YIN et al., 20I2).

Throughout the experiment, we observed live grafts with low weld quality, with poor quality of tissues union between scion and rootstock (Figure 5B). Other studies also observed reduced graft survival when working with patch grafts (KOTZ et al., 20I I; WENDLING et al., 20I6), which caused poor cicatrization of the bud, and led to graft death. However, further studies are needed to clarify these results.

We observed the highest rates of graft sprouting in 8 -year-old rootstocks, with plagiotropic propagules (75\%),
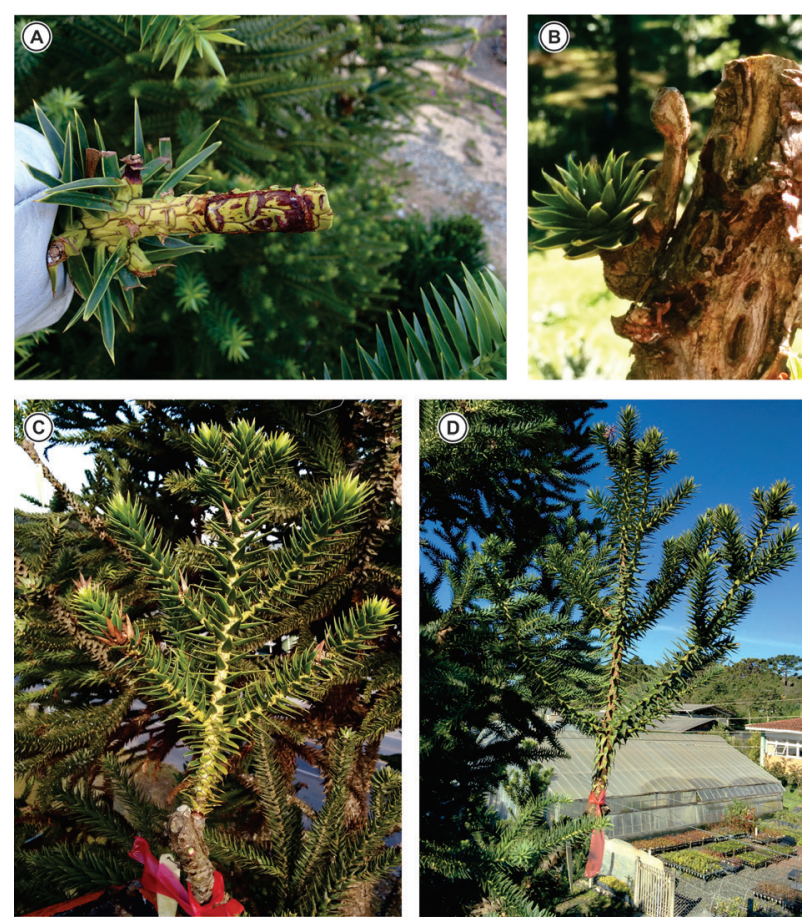

FIGURE 5 General aspects of the grafts: (A) Live graft 3 months after grafting, with apical portion of the grafted branch (rootstock) removed; (B) Live graft with low union (or weld) quality; (C) Orthotropic graft after 16 months in 35-year-old rootstock and (D) Orthotropic graft after 26 months in 8-year-old rootstock. followed by orthotropic propagules (46.9\%). However, for the number and average length of sprouts, we did not observe superiority when using young rootstocks, but we did notice a tendency for the number (NS) and average length of sprouts (ALS) to decrease from younger (8-yearold) to older rootstocks (35-year-old) (Table I).

Our results support the hypothesis of the positive effects generated by using young rootstocks (8-yearold), which states that juvenile characteristics of them associated with the quality of propagation material and application technique result in higher survival rates and vigor of the grafts.

Regarding sprout emissions (PS) of grafts performed in the spring/2015, we did not observe any significant differences for the analyzed variables. However, we did observe higher values of NS and ALS (Table 2) for the 8-year-old rootstocks compared to 35-years-old. PS and ALS values were lower for 35-year-old grafts than for 8-year-old grafts, showing that the maturation stage of the rootstocks may indicate morphological and physiological limitations for these two variables.

Top grafting technique is widely used for conifers from genus Pinus in Brazil and throughout the world, and usually aims at precocity for strobiles production, which, in some cases, it is achieved in the first year after grafting. For araucaria, such grafting technique have gone unpublished and there are no reports in the literature that indicate suitable methods. In general, the results presented in this study demonstrate the importance of using suitable materials for efficient top grafting, especially in respect to

TABLE I Emission percentage (EB), mean number (NB) and mean length of shoots (CMB) as a function of growth habit and age of rootstock at 16 months after grafting performed in fall/20I5 and spring/20I5.

\begin{tabular}{|c|c|c|c|}
\hline \multicolumn{4}{|c|}{ Fall/20I5 } \\
\hline TREATMENTS* & $\mathrm{EB}(\%)$ & NB (\%) & CMB (\%) \\
\hline TI & $46.9 \mathrm{ab}$ & $1.1 \mathrm{a}$ & $20.9 \mathrm{a}$ \\
\hline $\mathrm{T} 2$ & $75.0 \mathrm{a}$ & $1.3 \mathrm{a}$ & $34.4 \mathrm{a}$ \\
\hline T4 & $12.5 \mathrm{~b}$ & $1.0 \mathrm{a}$ & $15.0 \mathrm{a}$ \\
\hline Averages & 44.8 & I.I & 23.4 \\
\hline Variation coefficients (\%) & 45.9 & 16.2 & 44.8 \\
\hline \multicolumn{4}{|c|}{ Spring/20I5 } \\
\hline TREATMENTS* & $\mathrm{EB}(\%)$ & NB (\%) & CMB (\%) \\
\hline TI & $41.7 \mathrm{a}$ & $1.0 \mathrm{a}$ & $33.8 \mathrm{a}$ \\
\hline $\mathrm{T} 2$ & $40.6 \mathrm{a}$ & $\mathrm{I} . \mathrm{I} \mathrm{a}$ & $32.8 \mathrm{a}$ \\
\hline T3 & $31.3 \mathrm{a}$ & $1.0 \mathrm{a}$ & $25.4 \mathrm{a}$ \\
\hline T4 & $18.8 \mathrm{a}$ & $1.0 \mathrm{a}$ & I7.I a \\
\hline Averages & 33.1 & 1.0 & 27.3 \\
\hline Variation coefficients (\%) & 50.9 & 15.6 & 44.7 \\
\hline
\end{tabular}

Means followed by the same lowercase letter in the column do not differ from each other by the Tukey test $(\mathrm{P}<0.05)$. Where: $\mathrm{TI}$ : 8-year-old rootstocks and orthotropic grafts; T2: 8-year-old rootstocks and plagiotropic grafts; T3: 35-year-old rootstocks and plagiotropic grafts; T4: 35-year-old rootstocks and orthotropic grafts. 
the grafts vigor and age. Furthermore, top grafting is a viable technique for this species, which raises the hypothesis of better survival rates when using younger branches.

Although no other studies have focused on araucaria top grafting, the results obtained from grafting young plants ( $1-3$ years) show that our results can be considered adequate (GURGEL et al., 1967; KAGEYAMA et al., 1975; ZANETTE, 20II; CONSTANTINO; ZANETTE, 20I5; WENDILING, 20II; WENDILING, 2015; WENDILING et al., 2016). Another important result of this study is that we could verify that after grafting, the original growth habits of the grafts were maintained, i.e., plagiotropic grafts gave rise to plagiotropic shoots and orthotropic grafts (trunks), giving rise to orthotropic ones, even if grafting is made on branches.

\section{CONCLUSION}

Top grafting is a feasible technique for Araucaria angustifolia, with better results using younger rootstocks (8-year-old) and plagiotropic grafts. Growth habits of the grafts are maintained identically as original, independently of the rootstock growth habit.

\section{ACKNOWLEDGMENTS}

Support for this research came from the Empresa Brasileira de Pesquisa Agropecuária (EMBRAPA Florestas) and the Universidade Federal do Paraná - UFPR.

\section{REFERENCES}

ALMQVIST, C. Survival and strobili production in topgrafted scions from young Pinus sylvestris seedlings. Scandinavian Journal of Forest Research, v. 28, n. 6, p. 533-539, 20 I 3a.

ALMQVIST, C. Interstock effects on topgraft vitality and strobili production after topgrafting in Pinus sylvestris. Canadian Journal of Forest Research, v. 43, n. 6, p. 584-588, 20I3b.

BOND, B. J.; CZARNOMSKI, N. M.; COOPER, C.; DAY, M. E.; GREENWOOD, M. S. Developmental decline in height growth in Douglas-fir. Tree Physiology, v. 27, n. 3, p. 44I453, 2007.

CORDENUNSI, B. R.; MENEZES, W. E.; GENOVESE, M. I.; COLLI, C.; GONÇALVES, A. S.; LAJOLO, F. M. Chemical composition and glycemic index of Brazilian pine (Araucaria angustifolia) seeds. Journal of Agricultural and Food Chemistry, v. 52, p. 34I2-34I6, 2004.

CONSTANTINO, V.; ZANETTE, F. Produção de borbulhas ortotrópicas para enxertia de Araucaria angustifolia. Acta Biológica Paranaense, v. 44, p. I-4, 2015.

DANNER, M. A.; ZANETTE, F; RIBEIRO, J. Z. Plantation of Brazilian pine for nuts production as a conservation tool. Brazilian Journal of Forestry Research, v. 32, p. 44I-45I, 2012.

DIAS, P. C.; OLIVEIRA, L. S.; XAVIER, A.; WENDLING, I. Estaquia e miniestaquia de espécies florestais lenhosas do Brasil. Pesquisa Florestal Brasileira, v. 32, n. 72, p. 453$462,2012$.

GONÇALVES, P. M.; NOREÑA, C. P. Z.; SILVEIRA, N. P.; BRANDELLI, A. Characterization of starch nanoparticles obtained from Araucaria angustifolia seeds by acid hydrolysis and ultrasound. Food science \& technology, v. 58, n. I, p. $21-27,2014$.

GREENWOOD M. S., DAY, M. E., SCHATZ, J. Separating the effects of tree size and meristem maturation on shoot development of grafted scions of red spruce (Picea rubens). Tree Physiology, v. 30, p. 459-468, 2010.

GURGEL, J. T. A.; GURGEL-FILHO, C. A. Métodos de enxertia para o pinheiro brasileiro Araucaria angustifolia (Bertol.) O. Ktze., visando à formação de pomares de sementes. Sivilcultura, v. 6, p. I53- I55, 1967.

HARTMANN, H. T.; KERSTER, D. E.; DAVIES JR, F. T.; GENEVE, R. L. PLANT PROPAGATION: principles and practices. 8 ed. Boston: Prentice Hall. 2011 . 915 p.

IBA - Indústria Brasileira de Árvores. Relatório 2017. Available at: $\quad$ http://www.iba.org/pt/biblioteca-iba/publicacoes. Accessed in: 22/09/2017.

JAYAWICKRAMA, K. J. S.; JETT, J. B.; MCKEAND, S. E. Rootstock effects in grafted conifers: A review. New Forest, v. 5, p. |57-|73. 199|.

JOHKAN, M.; MITUKURI, K.; YAMASAKI, S.; MORI, G.; ODA, $M$. Causes of defolation and low survival rate of grafted sweet pepper plants. Scientia Horticulturae, v. I19, p. 103-107, 2009.

KAGEYAMA, P. Y.; FERREIRA, M. Propagação vegetativa por enxertia de Araucaria angustifolia (Bert) $\mathrm{O}$. Ktze. Instituto de Pesquisas e Estudos Florestais, v. 12, p. 95-102, 1975.

KOTZ, T. E.; PIO, R.; CAMPAGNOLO, M. A.; CHAGAS, E. A.; DALASTRA, I. M. Enxertia em figueira 'Roxo de Valinhos' por borbulhia e garfagem. Bragantia, v. 70, n. 2, p. 344-348, 20 I I.

KUHN, S. A.; MARIATH, J. E. A. Reproductive biology of the "Brazilian pine" (Araucaria angustifolia - Araucariaceae): Development of microspores and microgametophytes. Flora - Morphology, Distribution, Functional Ecology of Plants, v. 5-6, n. 209, p. 290-299, 2014.

MARTÍNEZ-BALLESTA, M. C.; ALCARAZ-LÓPEZ, C.; MURIES, B.; MOTA-CADENAS, C.; CARVAJAL, $M$. Physiological aspects of rootstock-scion interactions. Scientia Horticulturae, v. I27, n.2, II2-I I8. 2010.

MEIER, A. R.; SAUNDERS, M. R.; MICHLER, C. H. Epicormic buds in trees: a review of bud establishment, development 
and dormancy release. Tree Physiology, v. 32, n. 5, p. 565-584, 2012.

MENCUCCINI, M.; MARTÍNEZ-VILALTA, J.; HAMID, H. A.; KORAKAKI, E.; VANDERKLEIN, D. Evidence for ageand size-mediated controls of tree growth from grafting studies. Tree Physiology, v. 3, n. 27, p. 463-473, 2007.

NAZARENO, A. G.; REIS, M. S. At Risk of Population Decline An Ecological and Genetic Approach to the Threatened Palm Species (Arecaceae) of Southern Brazil. Journal of Heredity, v. I, n. 105, p. I20-129, 2014.

OLIVEIRA, L. S. Enxertia, microenxertia e descrição do tropismo em Araucaria angustifólia (Bert.) O. Ktze. 2010. 90 p. Tese. Universidade Federal do Paraná, Curitiba.

PEREZ, A. M. M.; WHITE, T.L.; DUDLEY A. HUBER, D. A.; MARTIN, T. A. Graft survival and promotion of female and male strobili by topgrafting in a third-cycle slash pine (Pinus elliottii var. elliottii) breeding program. Canadian Journal of Forest Research, v. 37, p. I 244-I 252, 2007.

RONCATTO, G.; ASSIS, G. M. L. de; OLIVEIRA, T. K. de; LESSA, L. S. Pegamento da enxertia em diferentes combinações de variedades e espécies utilizadas como copa e como porta-enxertos de maracujazeiro. Revista Brasileira de Fruticultura, v. 33, n. 3, p. 948-953, $201 \mathrm{I}$.

SIMÃO, S. Manual de fruticultura. São Paulo: Ceres, 197I. $530 \mathrm{p}$.

WENDLING, I.; DUTRA, L. F; HOFFMANN, H. A.; BETTIO, G.; HANSEL, F. Indução de brotações epicórmicas ortotrópicas para a propagação vegetativa de árvores adultas de Araucaria angustifolia. Agronomía Costarricense, v. 2, n. 33, p. 309-319, 2009.
WENDLING, I. Enxertia e florescimento precoce em Araucaria angustifolia. Colombo: Embrapa Florestas, 2011. 7p. (Comunicado Técnico, 272).

WENDLING, I.; TRUEMAN, S. J.;XAVIER, A. Maturation and related aspects in clonal forestry-Part I: concepts, regulation and consequences of phase change. New Forests, v. 4, n. 45, p. 449-47I, 2014.

WENDLING, I. Tecnologia de enxertia de Araucaria angustifolia para produção precoce de pinhões, com plantas de porte reduzido. Embrapa Florestas, 20I5. 7 p. (Comunicado Técnico, 35I)

WENDLING, I.; STUEPP, C. A.; ZUFFELLATO-RIBAS, K. C. Araucaria angustifolia grafting: techniques, environments and origin of propagation material. Bosque, v. 37, n. 2, p. 285-293, 2016.

WENDLING, I.; ZANETTE, F.; RICKLI-HORSTI, H.; CONSTANTINO, V. Produção de mudas de araucária por enxertia. In: WENDLING, I.; ZANETTE, F. Araucária: particularidades, propagação e manejo de plantios. Brasília - DF, Embrapa, 2017. I59 p.

YIN, H.; YAN, B.; SUN, J.; JIA, P.; ZHANG, Z.; YAN, X.; CHAI, J.; REN, Z.; ZHENG, G.; LIU, H. Graft-union development: a delicate process that involves cell-cell communication between scion and stock for local auxin accumulation. Journal of Experimental Botany, v. 63, p. $4219-4232,2012$.

ZANETTE, F; OLIVEIRA, L. S.; BIASI, L. A. Grafting of Araucaria angustifolia through the four seasons of the year. Revista Brasileira de Fruticultura, v. 33, n. 4, p. 13641370, 2011. 